\title{
The Journal of Ecclesiastical
}

History

http://journals.cambridge.org/ECH

Additional services for The Journal of

Ecclesiastical History:

The

Journal of

Ecclesiastical

History

Email alerts: $\underline{\text { Click here }}$

Subscriptions: $\underline{\text { Click here }}$

Commercial reprints: $\underline{\text { Click here }}$

Terms of use : $\underline{\text { Click here }}$

Singing the new song. Literacy and liturgy in late medieval England. By Katherine Zieman. (The Middle Ages.) Pp. xvii+294 incl. 6 figs. Philadelphia: University of Pennsylvania Press, 2008. £39 (\$59.95). 9780812240511

Nicholas Orme

The Journal of Ecclesiastical History / Volume 60 / Issue 01 / January 2009, pp 164 - 164 DOI: 10.1017/S002204690800691X, Published online: 08 January 2009

Link to this article: http://journals.cambridge.org/abstract_S002204690800691X

How to cite this article:

Nicholas Orme (2009). The Journal of Ecclesiastical History, 60, pp 164-164 doi:10.1017/S002204690800691X

Request Permissions : $\underline{\text { Click here }}$ 
Singing the new song. Literacy and liturgy in late medieval England. By Katherine Zieman. (The Middle Ages.) Pp. xvii +294 incl. 6 figs. Philadelphia: University of Pennsylvania Press, 2008. £39 (\$59.95). 978 o 8I22 405I I

$7 E H$ (6o) 2009; doi:Io.IoI7/Soo220469080069IX

This book is best described as six essays on the reading and singing of Latin liturgical texts in late medieval England, since there is no strong overall framework nor any conclusion. The first four chapters seek to address the arrangements for learning to read and sing in schools; reading and singing as ideally practised in the choirs of religious houses; the sometimes defective reality of such practice; and reading as a devotional exercise by lay people without grammatical understanding. The remaining chapters centre on reading and singing in Piers Plowman and The Canterbury tales, especially those of the Prioress and Second Nun. The approach is that of a literary critic not an historian, especially in the language of exposition which is highly technical and theoretical by historical standards. The historical material comes largely through secondary works not original research, and fails (for this reviewer) to produce a clear systematic account of prayer and liturgy, their performance by clergy and lay people and their linear development: what changed (or did not) between I300 and I500. Some inconsistencies are apparent. At one point choristers are 'initiated into some form of clerical status' (p. ix); later they are 'pre-clerical' (p. 2I). The term 'song school' is said to 'appear regularly in medieval documents' (p. 5), but attention is subsequently drawn to the rarity of such references after I300 (p. I6). There are a number of questionable statements. Regarding chantry priests, for example, we are told that to engage one was potentially to deprive others of his ministrations (p. 94), whereas virtually all late medieval clergy were available for intercessory prayers and competed to say them. Chantry priests were not usually corporations sole like beneficed clergy (p. 96); 'contractual liturgy' was not confined to chantries and collegiate churches (p. 97) since all clergy who said prayers for the dead (including monks, friars and parish clergy) were working contractually; and it was not in principle scandalous to be hired to celebrate masses for a year at a time (p. I04). Altogether the book contains much that is speculative and at least a little that is disputable, to an extent that readers may sometimes find stimulating, but falls short of defining, explaining and advancing an interesting subject.

UNIVERSITY OF EXETER

Nicholas ORMe

A repertorium of Middle English prose sermons, I: Introduction, and Cambridge University Library to London, British Library (Additional); II: London, British Library (Arundel) to London, Westminster Abbey Library; III: Manchester, John Rylands University Library to Oxford, Bodleian Library; IV: Oxford, Hertford College to York, Borthwick Institute for Archives, plus indices. By Veronica O’Mara and Suzanne Paul. (Sermo. Studies on Patristic, Medieval, and Reformation Sermons and Preaching, r.) Pp. lxvii +9i6;

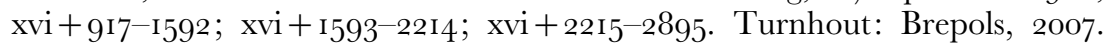
$€_{595.9782503519906}$

JEH (6o) 2009; doi:I0.1017/Soo220469o80o666o

The last thirty years have seen sermons move far more centre-stage in many areas of medieval studies. The SERMO project to publish catalogues of medieval European 